\title{
Effect of Tarragon (Artemisia dracunculus L.) and Its Ethanolic Extracts on Chronic Liver Disease in Male Albino Rats
}

\author{
Eman A. Ismail ${ }^{1}$, Eveleen S. Abdalla ${ }^{1}$, Ayman F. Khalil ${ }^{1}$ and Eshak M. El-Hadidy ${ }^{2}$ \\ 1-Home Economics Dept., Faculty of Specific Education, Ain Shams Univ., Egypt. \\ 2- Agricultural Research Center, Food Technology Research Institute, Egypt.
}

\begin{abstract}
Tarragon (Artemisia dracunculus L.) is a herb belonging to the Asteraceae family with a long history of protective effect and other medicinal benefits. This study aiming for studying Effect of Tarragon dried leaves and its ethanolic extracts (80\%) at different concentrations on chronic liver disease. Result of chemical composition of dried tarragon leaves (protein, carbohydrates, oil, fiber and ash (23.42, 48.53, 6.99 and $7.03 \mathrm{~g} / 100 \mathrm{~g}$, respectively) .It is rich in polyphenol, flavonoids and carotenoids contents $(28.5,15.45$ and $9.98 \mathrm{mg} / 100 \mathrm{~g}$, respectively). Antioxidants activity in dried of tarragon leaves was high(86.43\%) the major phenolic compounds were Benzoic acid, Catechein, Salycillic acid and Pyrogallol (1405.42, 8080.80, 252.71 and 213.25ppm, respectively). Also, flavonoids fractions indicated the highest content in Acacetin neo.rutinoside, Apig.6-arbinose8glactose, Apegnin, Luteolin 7-glucose and Hespirtin (907.70; 609.15; 576.54; 361.49 and 307.31 ppm, respectively). Sixty male albino rats weighted $(180 \pm 20 \mathrm{~g})$ were fed on basal diet for two weeks before the experiment were divided to ten main groups for 60 days as follows: $G 1$ (normal) and G2 induced $\mathrm{CCl}_{4}$, in paraffin oil $(50 \% \mathrm{v} / \mathrm{v} 2 \mathrm{ml} / \mathrm{Kg}$ ) twice weeks for chronic damage rats of liver rats and fed on basal diet. ( $\mathrm{G} 3$ normal and $\mathrm{G} 4$ induced $\mathrm{CCl}_{4}$ ) fed on diet containing tarragon powder $1 \%$ ,(G5 normal, and $\mathrm{G} 6$ induced $\mathrm{CCl}_{4}$ ) fed on diet containing tarragon powder $2 \%$, (G7 normal and G8 induced $\mathrm{CCl}_{4}$ ) treated orally with $(100 \mathrm{mg} / \mathrm{Kg}$ wt./day) tarragon extract. (G9 normal, G10 induced $\mathrm{CCl}_{4}$ ) treated with $200 \mathrm{mg} / \mathrm{kg}$ wt./day tarragon extract, orally. At the end of the experimental, serums were collected for determine liver and kidney functions. Results showed that decreased in AST , ALT and ALP in groups (9 and 10) which had oral tarragon extract (100 and $200 \mathrm{mg} / \mathrm{kg}$ ), while uric acid increased in $\mathrm{G} 10(47.67 \mathrm{mg} / \mathrm{dL})$, but was decreased creatinine in $\mathrm{G} 6(0.55 \mathrm{mg} / \mathrm{dL})$ which had taken $2 \%$ tarragon powder. Conclusively, tarragon extracts were significantly improved hepatorenal serum parameters in chronic liver disease rats groups.
\end{abstract}

Key words: Tarragon (Artemisia dracunculus L), Dried Leaves, Polyphenols, Flavonoids, Chronic Liver Disease. 


\section{Introduction:}

Chronic Liver Disease is a condition in which the liver slowly deteriorates and malfunctions due to chronic injury. Scar tissue replaces healthy liver tissue, partially blocking the flow of blood through the liver. Fibrosis begins with a long-lasting rather asymptomatic period (Pinter et al., 2016). It can lead to cirrhosis, hepatocellular carcinoma if left untreated and liver failure (Rajathi and Jiji, 2019).

People are interested in using herbal medicine because of side effects of chemical drugs. Plants are complementary and alternative medicine due to their ability for producing secondary metabolites such as; proteins, flavonoids, alkaloids, steroids, and phenolic compounds which are used to recover health (Moradi and Esfahani, 2016).

Tarragon (Artemisia dracunculus L.) is a perennial herb belonging to the Asteraceae family with a long history in culinary tradition and medicinal, it also possesses wide range of health benefits (Ribnicky, et al., 2014). Its taste is herbaceous with anise like (Obolskiy et al., 2011). Leaves smooth green and grown in warm, dry areas, grows in Egypt on Middle Sinai region (EISayed et al., 2009).Tarragon has a long history in food industry (flavoring of meat, sauces and vinegar) and cosmetics industry as well as medicinal use (Ekiert et al., 2021). It Contains antioxidants including monoterpenoids, sesquiterpenoids and isocoumarins, flavonoids, coumarin and alkamides (Eisenman et al., 2011). The extract of tarragon have anti-parasitic, anti-fungal, sedative, anti cough activity, immunomodulating and anti-tumour activities (Wang et al., 2011). Flavonoids have gained great interest as potential therapeutic agents against a wide variety of diseases. The most common flavonoids present in medicinal plants include quercetin, kaempferol, luteolin and apigenin (Duric et al., 2015).

Ibrahem, (2017) found that tarragon has a potential chemo-preventive effect against carcinogen-induced skin cancer in mice. The methanolic extract of tarragon dried aerial parts contains glycosides, volatile oils, alkaloids, terpenoids, phenolic compounds and flavonoids. Msaada et al., (2015) added that a gallic acid, widely used as an additive to prevent food spoilage, is renowned for its anti carcinogenic, anti-inflammatory, and antimutagenic activities. Study showed the presence of other flavonoid glycosides (isoquercitrin and quercetin-3-O- $\beta$-D-glucoside) in the samples. Kafshboran et al., (2011) showed that Flavonoids are a class of secondary plant phenolic, which act as pharmacological active compounds in many medicinal plants with their powerful antioxidant properties. Flavonoids have the basic skeleton of diphenyl propanes (C6-C3-C6) with various oxidation levels of the central pyran ring, they could provide strong antioxidant activities associated with their capacity to scavenge free radical and terminate radical chain. Therefore, this study aimed to evaluate Tarragon herb and its extracts as a hepato-protective plant. 


\subsection{Materials:}

Tarragon (Artemisia dracunculus L.) leaves was obtained from Herbs and Spices Company in Obour City El Kalubia, Egypt. Carbon tetrachloride $\left(\mathrm{CCl}_{4}\right)$ and ethanol (80\%) were obtained from Middle East Company Ind. Cairo, Egypt. Animals: sixty male albino rats weighed $180 \pm 20 \mathrm{~g}$ obtained from Experimental Animals unit in Food Technology Research Institute, Agricultural Research Center, Giza- Egypt.

\subsection{Methods:}

\subsubsection{Chemical Analyses of Dried Leaves Tarragon:}

- Chemical composition of Tarragon dried leaves (moisture, crude fiber, oil, protein, and ash contents) was determined according to methods of (A.O.A.C., 2000). Total carbohydrates were calculated by difference.

- Tarragon leaves was washed in aqueous several times to remove any adhering flesh, dried in oven under vacuum, then ground well. Ground tarragon was dipping in ethanol $80 \%$ (1:100 $\mathrm{w} / \mathrm{v}$ ) in dark bottle for $48 \mathrm{~h}$ in refrigerator at $4^{\circ} \mathrm{C}$ temperature. To obtain extracts, then mixtures were filtered by filter paper (Whatman1). Ethanolic solutions were evaporated in rotary evaporator at $50^{\circ} \mathrm{C}$ (El-Hadidy et al., 2018).

\subsubsection{Determination of Antioxidants Content:}

The content of total polyphenols in the Tarragon dried leaves was determined by using the FolinCiocalteu phenol reagent Amarowicz et al., (2004). Flavonoids were determined according to the methods of Chang et al., (2002). The free radical scavenging capacity of extracts was determined using DPPH by Burits and Bucar (2000). Also, Carotenoids as $\beta$-Carotene was determined according to the method of Nagata and Yamashita (1992). While, Volatile oil was determined by hydordistillation method (ISO 6571: 2009).

The capacity to scavenge activity the "stable" free radical DPPH (2,2-Diphenyl-1-picrylhydrazyl) was monitored according to the method of Takao et al. (1994).

\subsubsection{HPLC Determination of Phenolic and Flavonoid Compounds:}

Polyphenolic and Flavonoid compounds determined by HPLC according to method Mattila et al., (2000) and Goupy et al., (1999). 


\subsubsection{Diet Composition and Fed Animal Groups:}

1) Diet composition: Basal diet was prepared according to Reeves et al., (1993). The vitamin and mineral mixture had the prepared according to NCR, (1995).

2) Experimental design: Animal house in Food Technology Research Institute, Agriculture Research Center albino rats were adapted for one week prior to commencement of the experiment, housed in well aerated cages under hygienic condition and water introduced ad-libitum. After this week, thirty rats fed on basal diet and treated with $\mathrm{CCl}_{4}$ in paraffin oil $(50 \% \mathrm{v} / \mathrm{v} 2 \mathrm{ml} / \mathrm{Kg}$ ) twice weeks subcutaneous injection to induce chronic damage in the liver rats (Jayasekher et al., 1997) were divided into ten groups, six rats each as follow: G1, rats basal diet (Negative control), while G 2, rats induced $\mathrm{CCl}_{4}$ and basal diet till the end of experiment (Positive control). G3, rats basal diet+1\% tarragon powder. $\mathrm{G} 4$ : rats induced $\mathrm{CCl}_{4}$ and basal diet $+1 \%$ tarragon powder. $\mathrm{G} 5$, rats basal diet $+2 \%$ tarragon powder. $\mathrm{G} 6$, rats induced $\mathrm{CCl}_{4}$ and basal diet $+2 \%$ tarragon powder. $\mathrm{G} 7$, rats fed on basal diet+ Tarragon extract $100 \mathrm{mg} / \mathrm{Kg}$ b.w./day, orally .G8, rats induced $\mathrm{CCl}_{4}$ and basal diet+ Tarragon extract $100 \mathrm{mg} / \mathrm{Kg}$ b. w. /day, orally. Obolskiy et al., (2011) and Zarasvand et al., (2016) G9 rats basal diet+ Tarragon extract $200 \mathrm{mg} / \mathrm{Kg}$ b. w. /day, orally. G10, rats induced $\mathrm{CCl}_{4}$ and basal diet + Tarragon extract 200mg/ Kg b.w./day, orally (Modaresi et al., 2011).

\section{3-Assessment of Liver and Kidney Functions:}

At the end of experiment (after 2months), rats were fasted overnight and anesthetized and blood samples were taken for determination of Glutamate pyruvate Transaminase (ALT/GPT) and Glutamate Oxaloacetate Transaminase (AST/GOT) were determined according to Sherwin,(1984) .Serum Alkaline Phosphatase (ALP) was determined (IU/L) according to Tietz et al., (1999). Uric acid was determined according to Sherwin, (1984). Serum Creatinine was determined according to Bartles et al., (1973).

Statistical Analysis: The results were expressed as mean \pm SD. Data were analyzed by one-way analysis of variance (ANOVA).The differences between means were tested for significance using Bon ferroni-Dunn test at $(\mathrm{P}<0.05)$ according to pc-stat., (1985).

\section{$\underline{\text { Results and Discussion: }}$}

Chemical Compositions and Antioxidants of Dried Leaves Tarragon: The proximal composition and nutritive value of tarragon was presented in table (1). Leaves tarragon as shown in table (1) protein $(23.42 \pm 2.53 \mathrm{~g} / 100 \mathrm{~g})$, carbohydrate $(48.53 \pm 5.32 \mathrm{~g} / 100 \mathrm{~g})$. Moisture, fat, fiber and ash were 7.74 , $6.99,8.48$ and $7.03 \mathrm{~g} / 100 \mathrm{~g}$, respectively. 
INTERNATIONAL JOURNAL OF

FAMILY STUDIES, FOOD SCIENCE AND NUTRITION

HEALTH

Table :(1): Chemical Composition, Antioxidants Content and Its Activity of Dried Leaves Tarragon (g/100g) on Dry Weight Basis.

\begin{tabular}{|c|c|}
\hline Composition & $\mathrm{g} / 100 \mathrm{~g}$ \\
\hline Moisture & $7.74 \pm 0.93 *$ \\
\hline Crude protein & $23.42 \pm 2.53$ \\
\hline Crude Oil & $6.99 \pm 1.28$ \\
\hline Carbohydrate & $48.53 \pm 5.32$ \\
\hline Crude fiber & $8.48 \pm 0.93$ \\
\hline Ash & $7.03 \pm 1.25$ \\
\hline Total Polyphenols(TPC) & $28.5 \pm 1.85$ \\
\hline Total Flavonoids (TFC) & $15.54 \pm 2.83$ \\
\hline Total Carotenoids & $9.98 \pm 0.87$ \\
\hline Volatile oil (v/w, \%) & $0.30 \pm 0.03$ \\
\hline $\begin{array}{c}\text { Radical scavenging } \\
\text { activities(DPPH)\% }\end{array}$ & $86.43 \pm 2.85$ \\
\hline *Means (triplicate sample) & \\
\hline
\end{tabular}

*Means (triplicate sample) \pm SD

Iqbal et al., (2012) found that chemical compositions of (Artemisia Annua leaves )other type of tarragon summarized in percentage of protein $(24.37 \mathrm{~g} / 100 \mathrm{~g})$ dry weight, carbohydrate 48.3 , fat 6.07, fiber 14.2 , moisture $11.4 \mathrm{~g} / 100 \mathrm{~g}$ and protein). However, the ash content suggests a high amount of inorganic minerals in A. annua leaves. On the other hand, Brisibe et al., (2009), in the same type $A$. Annua leaves were the richest protein content; $(27.1 \%)$ and equally showed the compositions of fat.

Antioxidant Contents and Its Activity of Tarragon Extract: Tarragon herbs is rich in antioxidant contents as polyphenols, flavonoids, carotenoids, volatile oil and other items as shown is table (1) Results showed that total phenol $(28.5 \pm 1.85 \mathrm{mg} / \mathrm{g})$, flavonoids $(1.54 \pm 2.83 \mathrm{mg} / \mathrm{g})$, total carotenoids $(9.98 \pm 0.87 \mathrm{mg} / 100 \mathrm{~g})$, volatile oil $(0.30 \pm 0.03 \% \mathrm{v} / \mathrm{w})$ and DPPH $(86.43 \pm 2.85 \%)$. Several studies proved that tarragon is strong antioxidants (Behbahani et al, 2017). Sahreen et al., (2010) mentioned that The antioxidant properties of phenolic and flavonoid are potent chelators of redoxactive metal ions and they can inactivate free radical chain reactions by hindering the conversion of hydroperoxides to reactive oxyradicals. While, Gawlik-Dziki, (2012) found that tarragon total phenolic content in aqueous extract of $A$. dracunculus $(26.2 \mathrm{mg} / \mathrm{g})$ and the phenolic content of ethanolic extracts of tarragon leaves about $27 \mathrm{mg} / \mathrm{g}$. Another study, Bandi and Hidari, (2014) mentioned that phenolic and flavonoid contents of methanol extracts of tarragon leaves showed higher values than the other two extracts. According to Sengul et al., (2011) studied the total phenolic content in Artemisia absinthum was $(9.79 \mathrm{mg} / \mathrm{g}$ ) followed by Artemisia santonicum (15.38 $\mathrm{mg} / \mathrm{g}$ ) and Saponaria officinalis $(6.57 \mathrm{mg} / \mathrm{g})$. while hydroxycinnamates were the main phenolic 
components of tarragon leaves (Lin and Harnly, 2012). Also, Zarezade et al., (2018) added that total phenolic content was $197.22 \pm 3.73 \mathrm{mg} / \mathrm{g}$ from gallic acid equivalent/g the hydro-alcoholic extract of aerial parts of Artemisia dracunculus dry weight. It's clear that, total phenolic of Artimisia 6.57 to $27 \mathrm{mg} / \mathrm{g}$ in the previous study types of tarragon.

\section{Polyphenols Fractions:}

\section{A- Analysis of Polyphenolic and Flavonoids Compounds by HPLC:}

Quantitative analysis of the identified compounds (Table 2) showed that the phenolic Compounds of the studied tarragon extract were predominated by Benzoic acid, Catechein, Pyrogallol, and Caffeine (1405.42, 808.80, 213.25 and 190.54 ppm, respectively). Concerning, flavonoids compounds of tarragon extract by Acacetin neo.rutinoside, Apig.6-arbinose8-glactose, Apegnin and Luteolin 7-glucose (907.70, 609.15, 576.54 and 361.49 ppm, respectively).

These data were adapted by Ibrahem, (2017), Msaada et al., (2015) and Kafshboran et al., (2011).

Table (2): Analysis of Polyphenolic and Flavonoids Compounds by HPLC in Tarragon Dried Leaves.

\begin{tabular}{|c|c|c|c|}
\hline $\begin{array}{l}\text { Polyphenolic } \\
\text { Compounds }\end{array}$ & ppm & Flavonoids & ppm \\
\hline Pyrogallol & 213.25 & $\begin{array}{l}\text { Apig.6-arbinose8- } \\
\text { glactose }\end{array}$ & 609.15 \\
\hline Gallic acid & 13.01 & Luteolin 7-glucose & 361.49 \\
\hline Protocatchuic acid & 70.36 & Naringin & 298.92 \\
\hline 4-Aminobenzoic acid & 9.85 & Rutin & 175.86 \\
\hline Catechein & 808.80 & Quercetrin-3-O-glucose & 21.98 \\
\hline Chlorogenic acid & 20.33 & Apigenin-7-glucose & 56.48 \\
\hline Catechol & 40.12 & $\begin{array}{l}\text { Apigenin-7-0- } \\
\text { neohespiroside }\end{array}$ & 119.94 \\
\hline P-OH-benzoic acid & 95.85 & $\begin{array}{l}\text { Kampferol 3-7- } \\
\text { diramoside }\end{array}$ & 255.92 \\
\hline Caffeic acid & 28.26 & Quercetrin & 124.17 \\
\hline Vanillic acid & 47.64 & Quercetin & 147.00 \\
\hline Caffeine & 190.54 & Naringenin & 15.39 \\
\hline P-coumaric acid & 9.59 & Acacetin neo.rutinoside & 907.70 \\
\hline
\end{tabular}


INTERNATIONAL JOURNAL OF

FAMILY STUDIES, FOOD SCIENCE AND NUTRITION

HEALTH

ISSN: $2735-5381$

VOLUME 4, ISSUE 2, 2021, 46-59.

www.egyptfuture.org/ojs/

\begin{tabular}{|c|c|c|c|}
\hline Ferulic acid & 42.96 & Hespirtin & 307.31 \\
\hline Iso-Ferulic acid & 12.88 & Kampferol & 169.63 \\
\hline Salycillic acid & 252.71 & Apegnin & 576.54 \\
\hline Benzoicacid & 1405.42 & - & - \\
\hline Coumarin & 45.22 & - & - \\
\hline $\begin{array}{c}\text { 3,4,5-methoxy- } \\
\text { cinnamic acid }\end{array}$ & 143.62 & - & - \\
\hline Cinnamic acid & 33.14 & - & \\
\hline
\end{tabular}

\section{Effect of Dried Tarragon and Its Extract on Serum Liver Parameters:}

Result of table (3) revealed the effects of tarragon powder and tarragon extract on the liver enzymes of normal and chronic liver diseases groups. It showed that tarragon powder and tarragon extract in normal groups G3, G5, G7 and G9 did not alter any values of the measured parameters ALT,AST and ALP significantly when compared to normal group (G1). However, tarragon powder and tarragon extract in $G 8$, and G10 induced a markedly significant reduction $(p<0.05)$ of the serum activities of the enzymes ALT (36.00 and $34.33 \mathrm{IU} / \mathrm{L})$, AST (2.63 and $2.60 \mathrm{IU} / \mathrm{L})$; when they are compared to the chronic liver disease G2 ALT (41.33 IU/L) and AST ( $2.73 \mathrm{IU} / \mathrm{L})$, respectively. On the other hand, ALP results showed a significant reduced in chronic liver disease groups G8 and G10 (1.88, and $1.86 \mathrm{IU} / \mathrm{L})$ respectively, regarding $\mathrm{G} 2$ (2.14 IU/L).

Table (3): Effect of Tarragon Dried Leaves and Its Extracts on Serum Liver Parameters

\begin{tabular}{|c|c|c|c|}
\hline Groups & $\begin{array}{c}\text { AST } \\
\text { (IU/L) }\end{array}$ & $\begin{array}{c}\text { ALT } \\
\text { (IU/L) }\end{array}$ & $\begin{array}{c}\text { ALP } \\
\text { (IU/L) }\end{array}$ \\
\hline G1 & $2.50 \mathrm{a} \pm 0.18$ & $29.67 \mathrm{de} \pm 2.07$ & $1.85 a b \pm 0.19$ \\
\hline $\mathrm{G} 2$ & $2.73 a \pm 0.46$ & $41.33 a \pm 9.40$ & $2.14 \mathrm{a} \pm 0.04$ \\
\hline G3 & $2.53 a \pm 0.31$ & 28.33 e \pm 4.13 & $1.83 a b \pm 0.04$ \\
\hline G4 & $2.73 a \pm 0.46$ & $41.00 \mathrm{ab} \pm 0.00$ & $2.05 a \pm 0.10$ \\
\hline G5 & $2.50 a \pm 0.15$ & 28.33 e \pm 4.13 & $1.76 a b \pm 0.20$ \\
\hline G6 & $2.70 \mathrm{a} \pm 0.50$ & $37.67 \mathrm{abc} \pm 2.58$ & $2.02 \mathrm{a} \pm 0.20$ \\
\hline G7 & $2.47 a \pm 0.31$ & $27.00 \mathrm{e} \pm 3.58$ & $1.76 a b \pm 0.43$ \\
\hline G8 & $2.63 a \pm 0.29$ & $36.00 b c \pm 4.47$ & $1.88 \mathrm{ab} \pm 0.26$ \\
\hline G9 & $2.40 \mathrm{a} \pm 0.24$ & $25.67 \mathrm{e} \pm 2.07$ & $1.53 \mathrm{~b} \pm 0.71$ \\
\hline G10 & $2.60 a \pm 0.24$ & $34.33 \mathrm{~cd} \pm 2.58$ & $1.86 a b \pm 0.23$ \\
\hline
\end{tabular}

Data are presented as mean ( $n=6$ rats). All results are expressed as mean \pm SD .Values in each column which have different letters are significantly different $(p<0.05)$. 


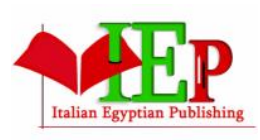

ISSN: $2735-5381$
INTERNATIONAL JOURNAL OF

FAMILY STUDIES, FOOD SCIENCE AND NUTRITION

HEALTH

VOLUME 4, ISSUE 2, 2021, 46-59.

G1:normal no treatment, $\mathrm{G} 2$ : induced $\mathrm{CCL}_{4}+$ no treatment, $\mathrm{G} 3$ :normal $1 \%$ tarragon dry G4: induced $\mathrm{CCL}_{4}+1 \%$ tarragon dry ,G5: normal $2 \%$ tarragon dry , G6: induced $\mathrm{CCL}_{4}+2 \%$ tarragon dry, G7: normal 100mg tarragon extract, G8: induced $\mathrm{CCL}_{4}+100 \mathrm{mg}$ tarragon extract, G9: normal 200mg tarragon extract $\mathrm{G} 10$ : induced $\mathrm{CCL}_{4}+200 \mathrm{mg}$ tarragon extract.

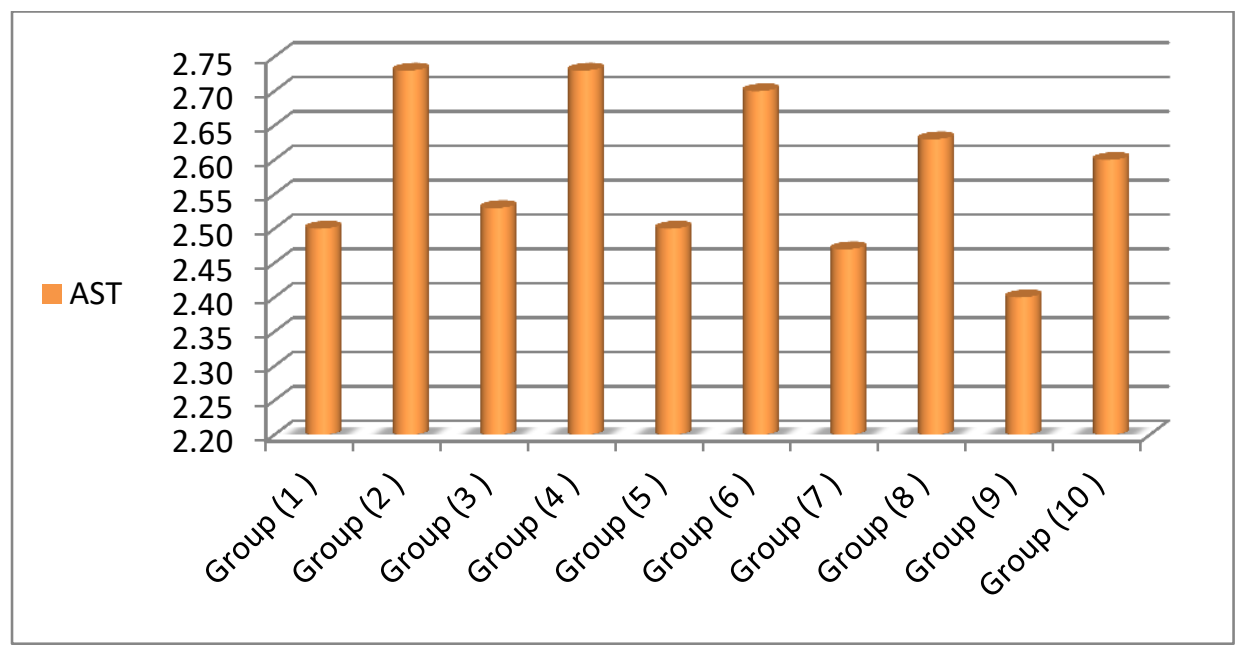

Fig(1): Effect of tarragon powder and tarragon extract on AST (IU/L) for normal and chronic liver disease rats.

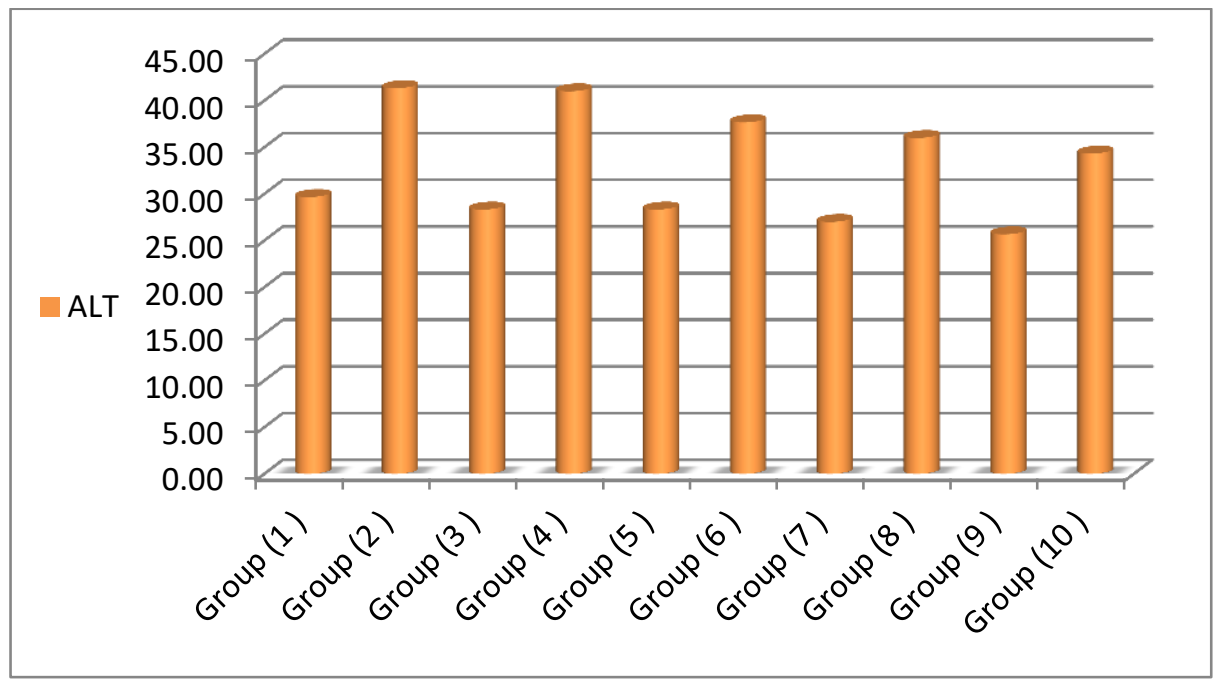

Fig. (2): Effect of tarragon powder and tarragon extract on ALT (IU/L) for normal and chronic liver disease rats 


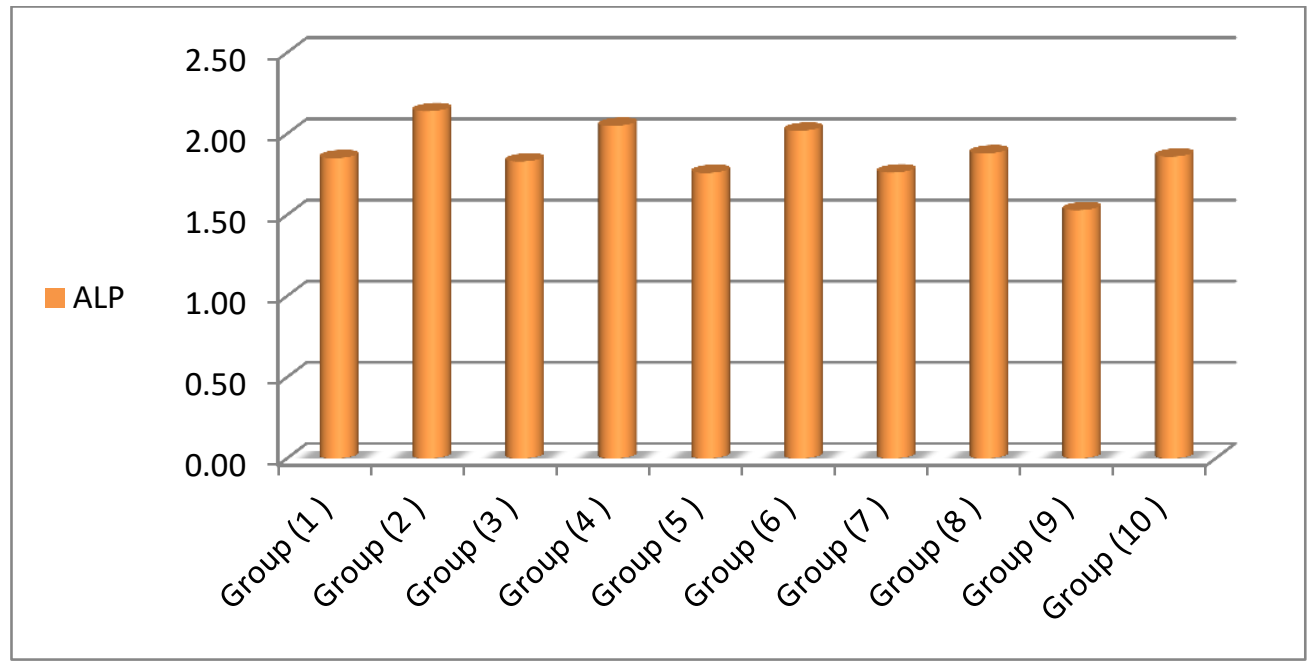

Fig (3): Effect of tarragon powder and tarragon extract on ALP (IU/L) for normal and chronic liver disease rats

Effect of Dried Leaves Tarragon and Tarragon Extract on Kidneys Functions for Normal and Chronic Liver Disease Rats:

tarragon powder and tarragon extract in normal groups G3 and G5 increased a significant alteration in serum uric acid and creatinine levels regarding the normal G1 the chronic liver disease groups G4, and G8 showed significant reduction of serum Uric acid levels (30.67 and 25.33$) \mathrm{mg} / \mathrm{dL}$ respectively, in comparison with the mean value recorded in chronic liver disease $G 2$ (35.33 mg/ dL). A statistically significant decrease $(p<0.05)$ in the level of creatinine for chronic liver disease groups G6 $(0.55 \mathrm{mg} / \mathrm{dL})$, when compared with group (G2).

Table(4): Effect of Tarragon Dried Leaves and Its Extracts on Kidneys Functions

\begin{tabular}{|c|c|c|}
\hline Groups & $\begin{array}{c}\text { Uric acid } \\
(\mathbf{m g} / \mathbf{d L})\end{array}$ & $\begin{array}{c}\text { Creatinine } \\
\text { (mg/dL) }\end{array}$ \\
\hline G1 & $32.33 \mathrm{c} \pm 1.03$ & $0.74 \mathrm{ab} \pm 0.08$ \\
\hline G2 & $35.33 \mathrm{bc} \pm 4.41$ & $0.60 \mathrm{~cd} \pm 0.04$ \\
\hline G3 & $40.00 \mathrm{~b} \pm 5.59$ & $0.61 \mathrm{~cd} \pm 0.10$ \\
\hline G4 & $30.67 \mathrm{c} \pm 1.86$ & $0.61 \mathrm{bcd} \pm 0.08$ \\
\hline G5 & $32.33 \mathrm{c} \pm 4.13$ & $0.67 \mathrm{abcd} \pm 0.09$ \\
\hline G6 & $31.67 \mathrm{c} \pm 5.75$ & $0.55 \mathrm{~d} \pm 0.09$ \\
\hline $\mathrm{G} 7$ & $25.00 \mathrm{~d} \pm 6.75$ & $0.75 \mathrm{a} \pm 0.15$ \\
\hline G8 & $25.33 \mathrm{~d} \pm 6.47$ & $0.79 \mathrm{a} \pm 0.05$ \\
\hline G9 & $39.33 \mathrm{~b} \pm 1.03$ & $0.72 \mathrm{abc} \pm 0.15$ \\
\hline G10 & $47.67 \mathrm{a} \pm 4.03$ & $0.70 \mathrm{abc} \pm 0.06$ \\
\hline
\end{tabular}

Data are presented as mean ( $n=6$ rats).All results are expressed as mean \pm SD .Values in .each column which have different letters are significantly different $(p<0.05)$. 


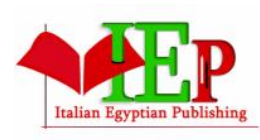

ISSN: $2735-5381$
INTERNATIONAL JOURNAL OF

FAMILY STUDIES, FOOD SCIENCE AND NUTRITION

HEALTH

VOLUME 4, ISSUE 2, 2021, 46-59.

G1:normal no treated, G2: induced CCL4 + no treated, G3:normal 1\% tarragon dry G4: induced CCL4 + 1\% tarragon dry ,G5: normal $2 \%$ tarragon dry , G6: induced CCL4 + $2 \%$ tarragon dry, G7: normal 100mg tarragon extract, G8: induced CCL4 +100mg tarragon extract, G9: normal 200mg tarragon extract G10: induced CCL4+200mg tarragon extract.

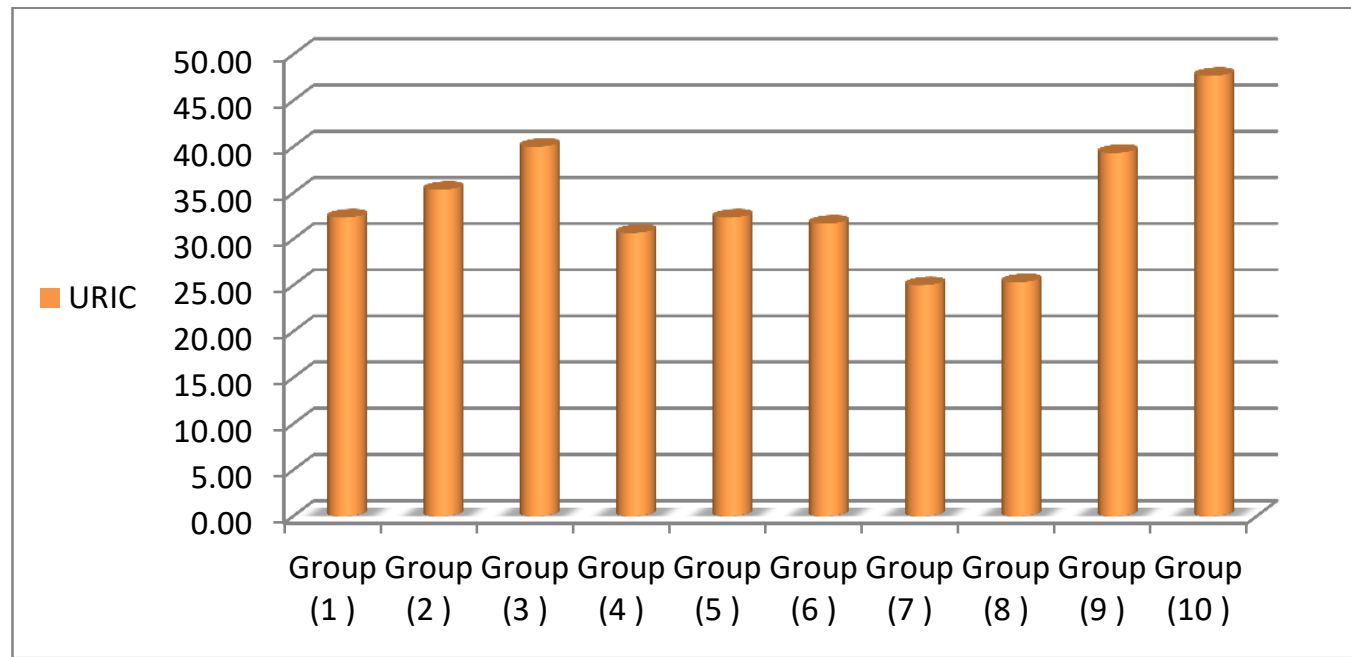

Fig. (4): Effect of tarragon powder and tarragon extract on Uric acid (mg/dL) for normal and chronic liver disease rats.

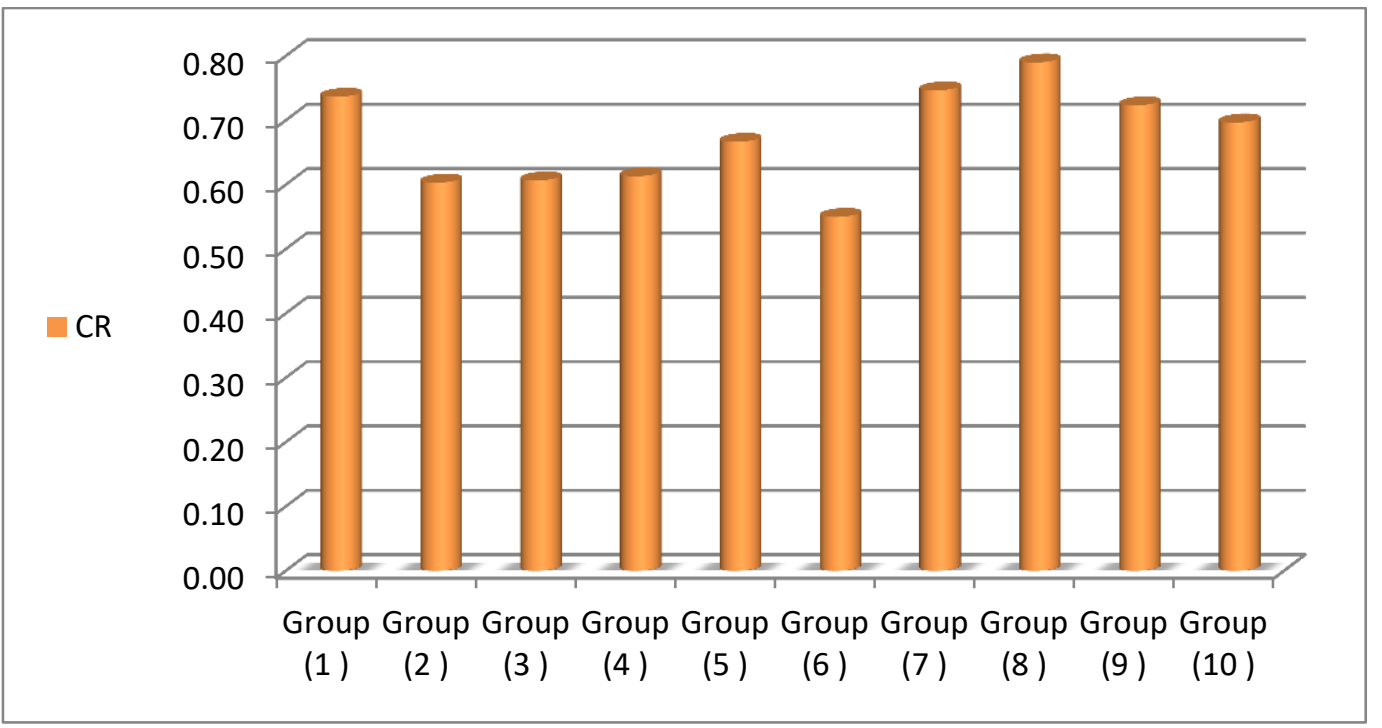

Fig. (5): Effect of tarragon powder and tarragon extract on Creatinine (mg/dL) for normal and chronic liver disease rats. 
These data were adapted by Zarezade et al., (2018) the hepatoprotective activity of a hydroalcoholic extract of the herb of tarragon, rats were given 50,100 , or $200 \mathrm{mg} / \mathrm{kg}$ of the extract for 15 days, followed by a single dose of carbon tetrachloride. Evidence was documented of a reduction in the levels of alanine transaminase, aspartate transaminase, alkaline phosphatase and total bilirubin, as well as a total protein increase. At different doses offered hepatoprotection, but $200 \mathrm{mg} / \mathrm{kg}$ of HEAD was more effective than the other doses.These data were adapted by Yazdani et al., (2013) the study showed that No significant changes in liver factors were observed with treatment of extract of Artemisia deserti. Whereas Iriadam et al., (2006) indicated that A. herba alba aerial parts aqueous extract caused reductions in ALT and AST. In the other study no significant changes were observed in the serum ALT activities, however, the value of AST increased after 3 month oral administration of single dose (100 and $1000 \mathrm{mg} / \mathrm{kg}$ ) of Artemisia afra aqueous extract. Also, suggesting that the AST activity levels increased with time, but ongoing treatment with high dose of aqueous extract removed this elevation, also, the extract may have a liver protecting effect Mukinda and Syce, (2007). Also, Soqeer (2011) conclude that the activity of AST was significantly reduced next management of $A$. monosperma extract in rat. This extract was increased antioxidant enzymes so for this reason, the rate of AST was reduced Kim et al., (2012).

These data were adapted by Choi et al., (2013), they reported that the clinical uses of Artemisia capillaries is beneficial for hepatic disorders which is associated with alcohol and its mechanisms may involve both augmentation of antioxidant actions and modulation of proinflammatory cytokines. reported that administration of Artemisia capillaris extract in high-fat diet (HFD) serum AST and ALT significantly decreased compared to HFD-control group (Habib et al., 2013).Oral treatment with the hydro-alcoholic extract of aerial parts of tarragon exhibited a significant decrease in the levels of AST, ALT, ALP, the extract showed a good concentrationdependent reducing power, which was consistent with the findings of Rajabian et al.,(2016).

Conclusively, tarragon extracts $200 \mathrm{ppm}$ was better than other treatment compared to normal treatment.

\section{$\underline{\text { References }}$}

1. A.O.A.C., (2000). "Official Methods of Analysis". 17th Edition, the Association of Official Analytical Chemists, Gaithersburg, MD, USA. Methods 925.10, 65.17, 974.24, 992.16.

2. Adam, S.; Al-Qarawi, A. and Elhag, E. (2000). Effects of various levels of dietary Artemisia abyssinica leaves on rats. Lab Animal. 2000; 34:307-312. [PubMed]

3. Al-Soqeer, A. (2011). Antioxidant activity and biological evaluation of hot-water extract of Artemisia monosperma and Capparis spinosa against lead contamination". Res. J. Bot., 6: 11-20. 
4. Amarowicz, R.B.; Pegg, P.; Rahimi-Moghaddam, B. and Barl J.A. (2004). Free-radical scavenging capacity and antioxidant activity of selected plant species from the Canadian prairies. J. Food Chem., 84: 551-562

5. Bartles, H.; Bohmer, M.; Heirli C. and Clin, C. (1973). Larsen K., Clin .Chem. Acta 41:209.

6. Behbahani,B.A.; Shahidi,F.; Yazdi,F.T.; Mortazavi, S.A. and Mohebbi, M.(2017). Antioxidant activity and antimicrobial effect of tarragon (Artemisia dracunculus) extract and chemical composition of its essential oil." J. Food Measurement and Characterization, 11: 847-863.

7. Brisibe, E.A.; Umoren, E.; Pedro, M.; Jorge F.S.; Devan, F. L .; Wu, X. and Prior, R. (2009). "Nutritional characterisation and antioxidant capacity of different tissues of Artemisia annua L". Food Chemistry, 115(4): 1240-1246.

8. Burits, M. and Bucar, F. (2000). Antioxidant activity of Nigella sativa essential oil. Phytother. Res.; 14: $323-328$.

9. Chang, C.C.; Yang, M.H.; Wen, H. M. and Chern, J.C. (2002). Estimation of total flavonoid content in propolis by two complementary colourimetric methods. J. Food and Drug. Analysis, 10:178-182.

10. Choi, M.K.; Han, J.M.; Kim, H.G.; Lee, J.S.; Lee, J.S. and Wang, J.H. (2013). Aqueous extract of Artemisia capillaris exerts hepatoprotective action in alcohol- pyrazole-fed rat model." J. Ethnopharmacol., 147(3):662-70. doi: 10.1016/j.jep.2013.03.065.

11. Duric, K.; Elvira, E.; Samija , H.N. and Sofi, M.E . (2015). Anticoagulant activity of some Artemisia dracunculus leaf extracts". Bosn. J. Basic. Med. Sci.; 15 (2):9-14.

12. Eisenman, S.; Poulv, A.; Struwe, L.; Raskin, I. and Ribnicky, D. (2011). Qualitative Variation of antidiabetic compounds in different tarragon cytotypes. Fitoterapia, 82(7):1062-1074

13. Ekiert, H.; Świątkowska, J.;Knut,E.; Klin,P.; Rzepiela,A.; Tomczyk,M. and Szopa,A.,(2021): "Artemisia dracunculus (Tarragon): A Review of Its Traditional Uses, Phytochemistry and Pharmacology" Pharmacol., https://doi.org/10.3389/fphar.2021.653993.

14. El-Hadidy, E.M.; Refat,O.G.; Halaby, M.S.;. Elmetwaly, E.M. and Omar, A. (2018). Effect of Lion's Foot (Alchemilla vulgaris) on liver and renal functions in rats induced by CCl4". Food and Nutrition Sciences, 9: 46-62.

15. El-Sayed, A.A; Mahassen, M. A.; Sidky, H. A. and Maie, M. A. (2009). Effect of organic fertilizer and Egyptian rock Phosphate on the growth, chemical composition and oil production of tarragon (Artemisia dracunculus L.). J. Product. \& Dev., 14(1): 87- 110.

16. Gawlik-Dziki, U. (2012). Dietary spices as a natural effectors of lipoxygenase, xanthine oxidase, peroxidase and antioxidant agents. LWT- Food Sci. Technol., 47: 138 - 46.

17. Goupy, P., Hugues, M., Boivin, P. and Amiot, M.J. (1999). Antioxidant compounds of barley (Hordeum vulgare) and malt extracts. J. Sci. of Food and Agric., 79: 1625-1634.

18. Gupta, S.; Jyothi Lakshmi, A.; Manjunath, M. and Prakash, J. (2005). Analysis of nutrient and antinutrient content of underutilized green leafy vegetables". LWT Food Sci. Technol., 38: 339345.

19. Habib, M. and Waheed, I. (2013). Evaluation of anti-nociceptive, anti-inflammatory and antipyretic activities of Artemisia scoparia hydromethanolic extract". J. Ethnopharmacol., 145(1): 18-24. DOI: 10.1016/j.jep.2012.10.022.

20. Ibrahem, N.M. (2017). Extraction and characterization of Iraqi Artemisia dracunculus L. dried aerial parts extract though HPLC and GC-MS analysis with evaluation of its antitumor activity 
against, 12-dimethylbenze, anthracene induced skin cancer in mice." Inter. J. Pharmacy and Pharmaceutical Sci., 9(5). DOI:10.22159/ijpps.2017v9i5.16875.

21. ISO 6571 (2009). Spices, condiments and herbs- Determination of volatile oil content (hydrodistillation method).

22. Iqbal, S.; Younas,U.; Chan, K.W. and Ismail, M. (2012). Chemical composition of Artemisia annua L. leaves and antioxidant potential of extracts as a function of extraction solvents." Molecules. 17(5). DOI:6020-32.doi: 10.3390/molecules17056020.

23. Iriadam, M.; Musa, D.; Gumushan, H. and Baba, F. (2006). Effects of two Turkish medicinal plants Artemisia herba-alba and Teucrium polium on blood glucose levels and other biochemical parameters in rabbits. J. Cell. Mol. Biol., 5: 19-24.

24. Jayasekhar, P.; Mohanan, P. V. and Rathinam, K. (1997). Hepatoprotectictive activity of ethyl acetate extract of Acacia Catechu. Indian J. Pharmacology, 29: 426-428.

25. Kafshboran, H.R.; Dehghan, G. and Aghdam, M.N. (2011). Investigation of radical scavenging potential of some populations of Artemisia spicigera in relation to their flavonoid content. International Conference on Life Science and Technology. 3: 207-215.

26. Kim, Y.J.; Kim, C.M.; Choi, J.H. and Choi, I.H. (2012). Effect of dietary mugwort (Artemisia vulgaris L.) and pine needle powder (Pinus densiflora) on growth performance, serum cholesterol levels, and meat quality in broilers. Afr. J. Biotech., 11: 11866-11873.

27. Lin, L.Z. and Harnly, J.M. (2012). LC-PDA-ESI/MS identification of the phenolic components of three compositae spices: chamomile, tarragon, and Mexican arnica. Nat. Prod. Commun.; 7 (6): $749-52$.

28. Mattila, P., Astola, J. and Kumpulainen, J. (2000). Determination of flavonoids in plant material by HPLC with Diode-Array and Electro-Array detections". J. Agric. and Food Chem., 48: 58345841. DOI:org/10.1021/jf000661f.

29. Modaresi, E.J.; Hanouneh, I. and Zein, N. (2011). A 25-year-old man with very high alkaline phosphatase". Clev .Clin. J. Med., 78: 793-800.

30. Moradi, P. and Esfahani R.E., (2016). Effect of foliar application methanol on the quality and quantity of Artemisia dracunculus L." Research Article plant biology, Electronic Journal of Biology, Vol.S1: 24-29.

31. Msaada, K.; Salem ,N.; Bacchrouch,O. and Bousselmi, S. (2015). Chemical composition and antioxidant and antimicrobial activities of wormwood (Artemisia absinthium L.) essential oils and phenolics. Journal of Chemistry, (2) DOI:10.1155/2015/804658.

32. Mukinda, J.T. and Syce, J.A. (2007). Acute and chronic toxicity of the aqueous extract of Artemisia afra in rodents. J. Ethnopharm., 112: 138-144.

33. Nagata, M. and I. Yamashita, I. (1992). Simple method for simultaneous determination of chlorophyll and carotenoids in tomato fruit. J. Food Sci. Technol., 39: 925-928.

34. Noori, A.; Amjad, L. and Yazdani F. ( 2014). The effects of Artemisia Deserti ethanolic extract on pathology and function of rat kidney. Avicenna J Phytomed., 4(6): 371-376.

35. Obolskiy, D.; Pischel, I.; Feistel, B.; Glotov, N .and Heinrich M. (2011). Artemisia dracunculus $L$. (Tarragon): A Critical Review of Its Traditional Use, Chemical Composition, Pharmacology, and Safety". J. Agric. Food Chem., 21 (59): 11367-11384.

36. -PC-stat, (1985): Version A copyright the university Georgia. 
37. Pinter, $M$.; Trauner, $M$.; Radosavljevic, $M$. and Sieghart,W. (2016). Cancer and liver cirrhosis: implications on prognosis and management." ESMO. Mar. 17; 1(2): e000042. doi: 10.1136/esmoopen-2016-000042.

38. Rabinicky, D.M.; Roopchand, D.E .; Poulev, A.; Kuhn, P .; Oren, A.; Cefalu ,W.T. and Raskin, I. (2014). Artemisia dracunculus L. polyphenols complexes to soy protein show enhanced bioavailability and hypoglycemic activity in C57BL/6 mice." Nutrition, 30(7-8 Suppl):S4-10. doi: 10.1016/j.nut.2014.03.009.

39. Rajabian, A.; Khayyat, M.H.; Emami, S.A.; Tayarani-Najaran,Z. ; Oskooie,R.R. and Asili, J. (2016). Phytochemical evaluation and antioxidant activity of essential oil, and aqueous and organic extracts of Artemisia dracunculus" J. Undishapur. J. Nat. Pharm, Prod. Inpress32325.

40. Rajathi, G.I and Jiji, G.W. (2019). Chronic liver disease classification using hybrid whale optimization with simulated annealing and ensemble classifier. Symmetr., 11: 33. doi:10.3390/sym11010033.

41. Reeves, P.G.; Nielson, F.H. and Fahmy, G.C. (1993). Report of Preformulation of the Ain 76ARodent diet. J. Nutrition, 123:1939-1951.

42. Safa, S.H.; Esteghamati, A.; Nasiri, M.; Foroutan, H.; Ghofrani, H.; Sarbyaei, A. and Abbasi M. (2005).The effects of liver dysfunction on serum lipoprotein levels in patients with cirrhosis and chronic hepatitis. Iranian J. Diabetes and Lipids Disorders, 5:153-161.

43. Sahreen, S.; Khan, M.R. and Khan, R.A. (2010). Evaluation of antioxidant activities of various solvent extracts of Carissa opaca fruits. Food Chem., 122, 1205-1211.

44. Sengul, M.; Ercisli, S.; Yildiz, H.; Gungor, N.; Kavaz, A. and Çetina, B. (2011). Antioxidant, antimicrobial activity and Total Phenolic Content within the Aerial Parts of Artemisia absinthum, Artemisia santonicum and Saponaria officinalis. Iran J .Pharm Res. 10(1): 49-56.

45. Sherwin, J.E., (1984). "Liver Function". In: Kaplan LA, Pesce AJ, eds .Clinical Chemistry, theory, analysis, and correlation. St. Louis: Mosby; 1984: 420-438.

46. Takao, T.: Watanabe,N.; Yagi ,I. and Sakata, K. (1994). A simple screening method for antioxidants and isolation of several antioxidants produced by marine bacteria from fish and shellfish, Biosci. Biotechnol. Biochem. 58: 1780-1783.

47. The National Research Council (NCR) (1995). Nutrient Requirements of Laboratory Animals: $4^{\text {th }}$ Revised Ed.

48. Tietz, N.W., Burtis, C.A., Ashwood, E.R. and Saunders, W.B. (1999). Textbook of Clinical Chemistry. 3rd Edition, W. B. Saunders Co., Philadelphia, 676-684.

49. Wang, Z.Q.; Ribnicky, D.; Zhang, X.H.; Zuberi,A.; Raskin,I.; Yu, Y. and Cefalu ,W.T. (2011). an extract of Artimisia dracunclus L. enhance insulin receptor signaling and modulates gene expression I $\mathrm{n}$ skeletal muscle in KK-A (y) mice. J. Nutrition Biochem., 22(1):71-78. DOI: 10.1016/j.jnutbio.2009.11.015

50. Yazdani, F.; Noor , A. and Amjad, L. (2013). Effect of Artemisia deserti flowering taps extract on liver in male rats. Int. J. Agric. Crop Sci., 5 (13), 1432-1436.

51. Zarasvand, M.; Madani, M. and Modaresi M.( (2016).The effect of hydroalcoholic extract of Artemisia dracunculus L. (Tarragon) on Candida albicans Infection in Mice". Journal of Natural Pharmaceutical Products. 11. DOI: 10.17795/jjnpp-29911.

52. Zarezade, V.; Moludi, J.; Mostafazadeh, M.; Mohammadi, M. and Ali Veisi, A. (2018). Antioxidant and hepatoprotective effects of Artemisia dracunculus against CCl4-induced hepatotoxicity in rats. Avicenna J. Phytomed, 8 (1): 51-62. 